Guttmann, L. (1946). Proc. Roy. Soc. Med. 40, 219.

GutTMANN, L. (I953). Brit. History of World War II, Vol. Surgery, 457. London: H. M. Stationery Office.

Hughes, J. T. (I966). Pathology of the Spinal Cord, p. 3. London: Lloyd-Luke.

Hughes, J. T. \& Brownell, B. (I963). F. Neurol. Neurosurg. Psychiat. 26, 528-534.

MAHER, R. M. (I955). Lancet, I, I8-20.

SHELDON, C. H. \& Bors, E. (I948). F. Neurosurg. 5, 385.

Smith, M. C. (1964). Brit. F. Anaesth. 36, 387-406.

Tank, T. M., Dohn, D. F. \& Gardner, W. J. (I963). Cleveland Clin. Quart. 30, i I I-I I 7.

\title{
AXON REGENERATION AFTER SPINAL CORD INJURY
}

\author{
By Lionel Wolman, M.A., M.D., PhD., M.R.C.P., D.P.M. \\ Department of Neuropathology, Royal Infirmary, Sheffield, 6
}

THE long-held belief that regeneration in the central nervous system does not occur has been questioned on numerous occasions both as a result of work on experimental animals and by observations on human pathological material. Thus regeneration within the central nervous system of amphibia has been demonstrated by Hooker (I915, I9I7, I925), Lorente de No (I921), McCreight (I924), Piatt (1955) and Stephens (1959). In mammals, after experimental transection of the cord, regeneration was shown by Denton (I873), Eichhorst and Naunyn (1874), Stroebe (I894), Nageotte (I899), Cajal (I928) and Murray et al. (I965). This regenerative capacity was much greater in embryonic or newborn animals (Gerard \& Grinker, I93I; Nicholas \& Rudnick, I933). Evidence of intraspinal sprouting of dorsal root axons with the development of new collaterals and preterminals following partial denervation of the spinal cord was shown in the cat by Liu and Chambers (1958). Regenerating fibres from both the cord tracts and spinal roots were demonstrated in the rat after cord transection by Sugar and Gerard (I940), but these observations could not be confirmed by Feigin et al. (I95I). Invasion of the spinal cord by axons from ventral nerve roots was demonstrated by Wohlfart (I96I).

In human material, the regenerative capacity of the central part of the posterior nerve roots has been frequently noted in spinal cord injury. The regenerated fibres entering the cord are covered with Schwann cells and are well myelinated. Thus Minor (I904) recognised bundles of myelinated fibres in the scar of the cord of patients with old traumatic lesions. Marinesco and Minea (I906) examined two cases of spinal cord compression due to dislocation of the first lumbar vertebra and found regenerated fibres accompanying blood vessels in the anterior median fissure, leptomeninges round the cord, in the posterior roots, in the scar and nearby grey matter. Henneberg (1907) found regenerating fibres in the leptomeninges covering the dorsal columns and extending into the cord in total transverse lesions of the cord. He believed they originated from posterior nerve roots. A similar origin was attributed by Klaue (I949) to the fibres seen in the scar of a grenade wound of the cord. 
Apart from traumatic cases, aberrant regenerating nerve fibres have been found in the cord in a variety of conditions where long-standing lesions are present. Thus Raymond (1893) first noticed them in the wall of a syrinx. Druckman and Mair (1953) found them in spinal cord compression by prolapsed intervertebral disc and by myeloma of the vertebral column in addition to syringomyelia. Hughes and Brownell (1963) described such fibres in nine cases of destructive lesions of the cord including syringomyelia, myelitis, trauma, poliomyelitis, and cord compression by tumour and by cervical spondylitis.

The problem of regeneration has been discussed by Windle (1955), and more recently he reviewed the present position and future possibilities (I962). In order to study the frequency and extent of regeneration in the human spinal cord a series of cases of traumatic paraplegia has been investigated. By confining the observations to patients with a definite spinal injury severe enough to cause paraplegia, the conditions resembled more closely those applicable to the experimental animal, the time sequence between trauma and pathological examination was known precisely and the possibility of assessing any functional potentiality in the regenerated fibres by clinical correlation with changing symptoms might become feasible.

\section{MATERIAL AND METHODS}

The spinal cords of 76 cases of traumatic paraplegia were examined at autopsy. The period of survival af ter injury ranged from 6 hours to 43 years. After fixation, transverse sections were taken from every segmental level from above downwards. Each was examined by the naked eye until macroscopic evidence of damage was recognised. The subsequent part of the cord was then serially sectioned to the lower border of the damaged segments, below which a block was taken from each of the remaining spinal cord segments. All histological findings were recorded in terms of spinal cord segments but the initial injury was expressed in relation to the bony vertebrae involved.

All the microscopical sections examined were stained by four routine methods which included haematoxylin and eosin, Mallory's phosphotungstic acidhaematoxylin, Nissl and a combined methasol fast blue-Holmes' silver stain to show both myelin sheaths and axis cylinders. Haematoxylin-Van Gieson and Masson's trichrome frequently combined with elastic tissue stain were found most useful in studying the fibrotic reaction and the vascular changes. Other myelin stains and the Holzer stain for gliosis were used when necessary. Stains for neutral fat on frozen sections were utilised when considered appropriate.

\section{RESULTS}

Evidence of well-developed axon regeneration in or near the damaged segments was found in 12 cases, although a few others had some tiny bundles of regenerated nerve fibres in the scar. The time elapsing after injury ranged from I 2 months to 32 years. In 3 of the 12 cases the trauma was in the cervical region, in 5 the thoracic cord was involved and in the remaining 4 the lumbar cord sustained injury. The relevant findings in the cases studied are shown below:

(I) G. B. Male, aged 69. Injury to C5. Survived I7 months. Several groups of regenerated nerve fibres present in the ventromedian fissure in $\mathrm{C}_{4}$ and 5 . 
(2) E. S. Female, aged 49. Fracture dislocation C6-C7. Survived 22 months. Several groups of regenerated nerve fibres present in the ventromedian fissure in $\mathrm{C} 8$ and DI (fig. I).

(3) F. G. Male, aged 47. Dislocation C6-7. Survived $2 \frac{1}{2}$ years. Regenerated nerve fibres most numerous near dorsal root entry zones, but also present in ventromedian fissure and in the thin shell of gliosed tissue surrounding the large transversely elongated cavity present in the most damaged segment $\mathrm{C}_{7}$ and in C6 (figs. 2A, B and C).

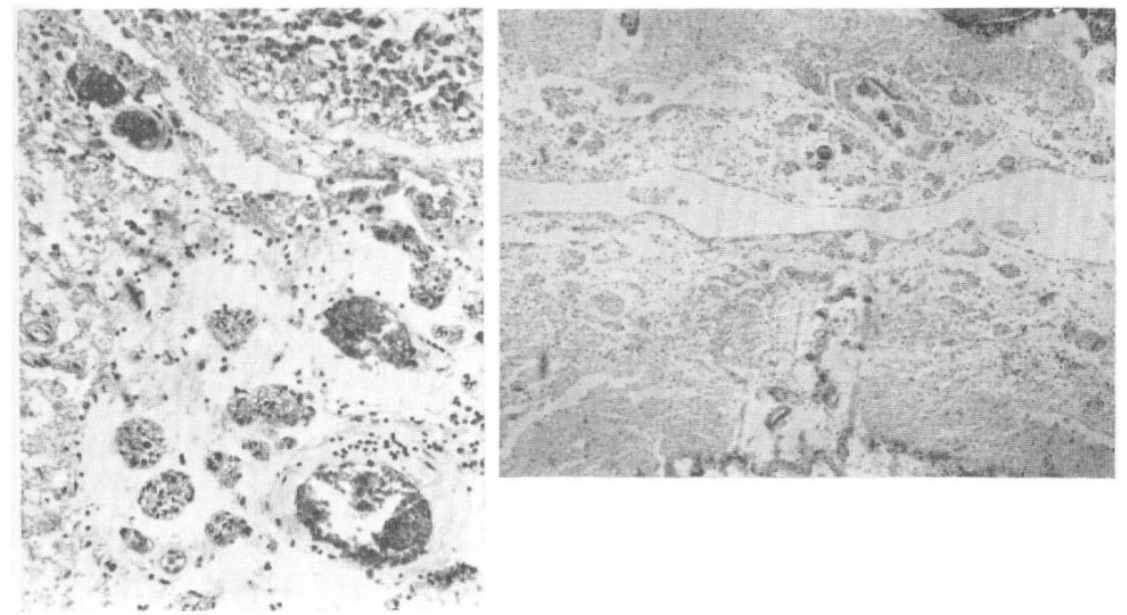

FIG. I

FIG. 2A

Figure I-Regenerated nerve fibres in pia arachnoid of ventromedian fissure at Dr. The ependymal lined central canal can be seen at the top. Fracture dislocation C6-7, 22 months previously. (H. \& E. × 100.) Figure 2A-Transverse section of spinal cord at $\mathrm{C}_{7}$ showing large cavity lined by a loose glial tissue in which are bundles of nerve fibres. Denser gliosis is present round the periphery. Dislocation C6-7, $2 \frac{1}{2}$ years previously. (H. \& E. $\times 30$.)

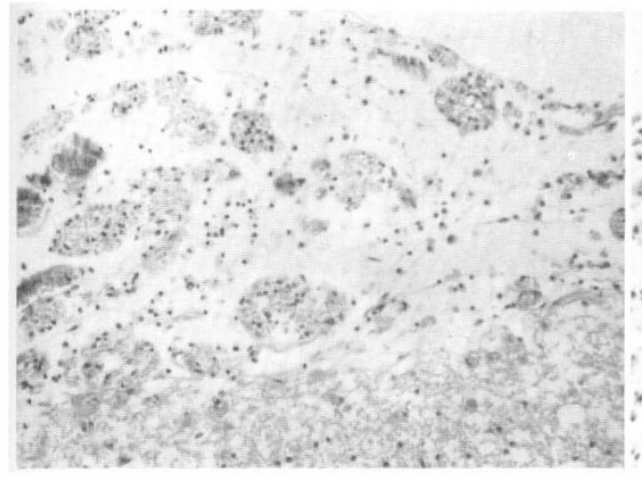

FIG. 2B

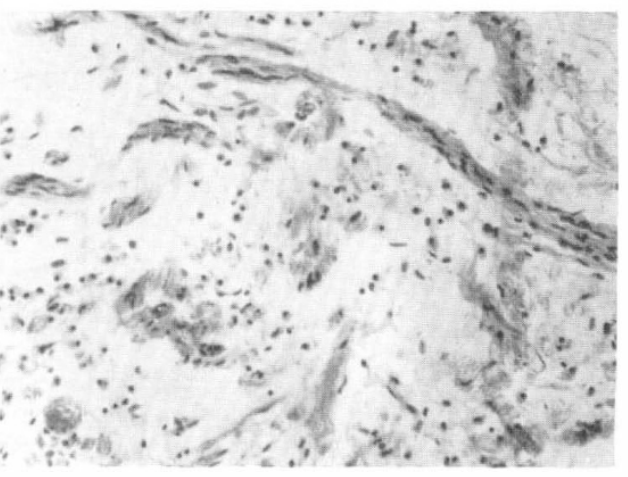

FIG. 2C

Figure $2 \mathrm{~B}-$ Some of the bundles of regenerated nerve fibres in ventral wall of cystic cavity at $\mathrm{C}_{7}$. (H. \& E. $\times 88$.) Figure $2 \mathrm{C}-$ Bundles of nerve fibres cut longitudinally in posterior wall of cystic cavity at C7. (H. \& E. × I02.) 
(4) K. S. Male, aged 35. Fracture dislocation D6-7. Survived $2 \frac{1}{2}$ years. Regenerated fibres in dorsal root entry zone, ventromedian fissure and around the cavity in the cord both above and below the site of maximum damage, extending from D6-L3.

(5) A. W. Male, aged 49. Fracture dislocation, Di I-I2. Survived $4 \frac{1}{2}$ years. At L4-5 the cord consisted of a dense mass of fibrous tissue, but above this as $\mathrm{LI}_{\mathrm{I}} 3$ it was replaced by many bundles of regenerated nerve fibres in a loose glial network (fig. $3 \mathrm{~A}$ ). Bundles of regenerated fibres could be traced in the thickened pia arachnoid on the dorsal surface as high as D6. Many bundles of regenerated fibres in a loose glial network in the sacral segments (fig. 3B).

(6) E. T. Male, aged 25. Fracture dislocation D4-5. Survived $5 \frac{1}{2}$ years. Maximal damage at $\mathrm{D}_{5}$ where cord replaced by a fibrous tag surrounded by thickened pia arachnoid.

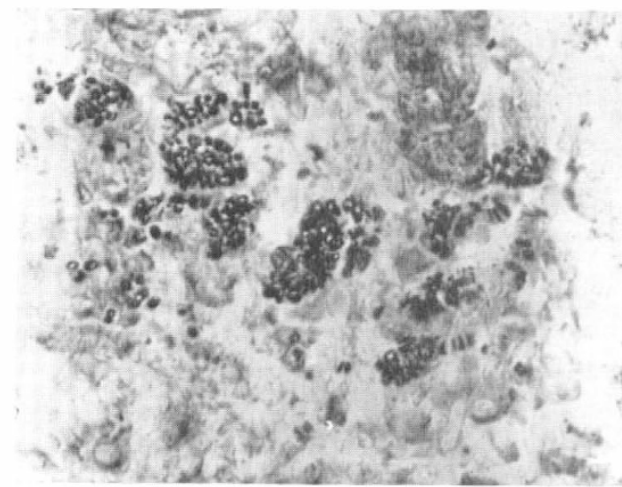

FIG. 3A

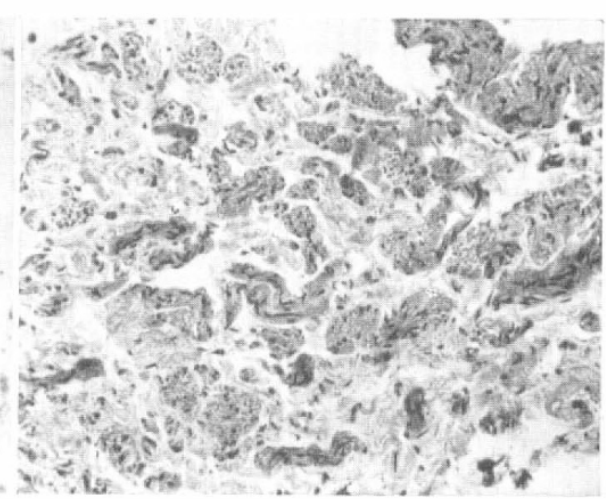

FIG. 3B

Figure $3 \mathrm{~A}-$ Transverse section at $\mathrm{L}$ I showing bundles of regenerated nerve fibres separated by a loose glial network, $4 \frac{1}{2}$ years after fracture dislocation DII-I2. (Silver $\times 200$.) Figure $3 \mathrm{~B}-$ Section through lower sacral segment of same case showing replacement of spinal cord by numerous bundles of regenerated nerve fibres. (H. \& E. $\times$ IOO.)

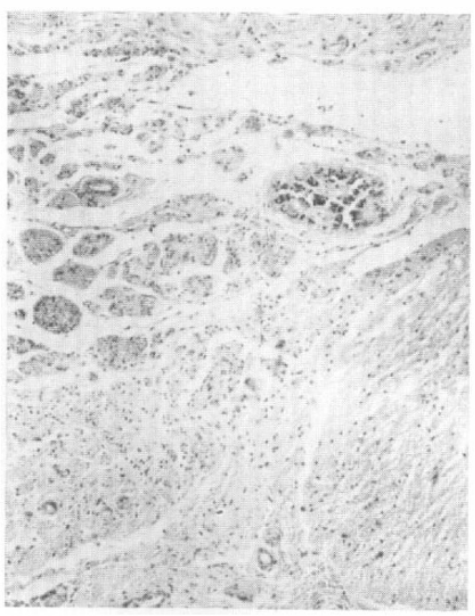

Fig. 4

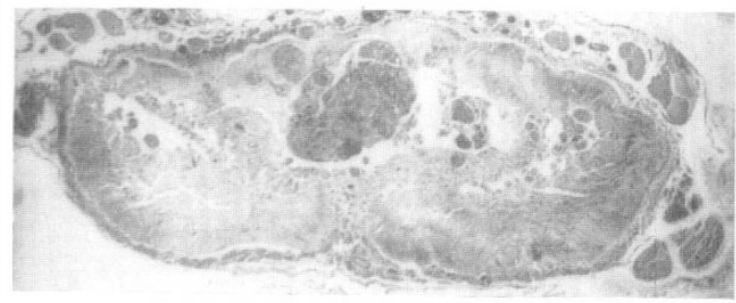

FIG. 5

Figure 4-Transverse section at $\mathrm{D}_{5}$ showing numerous bundles of nerve fibres in the wall of the cavity adjacent to the central canal extending into the ventromedian fissure, Io years after fracture dislocation of D5-6. (H. \& E. $\times 60$.) Figure 5 - Transverse section at D5 showing marked regeneration of both intramedullary fibres and of fibres in the thickened pia arachnoid on dorsal and ventral aspects, $17 \frac{1}{2}$ years after fracture dislocation $\mathrm{D} 4-5$. (Silver $\times 7 \frac{1}{2}$.) 
At $\mathrm{D}_{4}$ half the cord consisted of bundles of regenerated nerve fibres surrounded by a loose glial network with an outer rim of denser gliosed tissue which also occupied the other half of the cord.

(7) R. H. Male, aged 32. Fracture dislocation D5 on 6. Survived Io years. The cord was replaced by a fibrous mass at D6. At D4 and 5 the dorsal half of the cord consisted of a cystic cavity lined by gliosis in which were many bundles of regenerated fibres extending into the ventromedian fissure (fig. 4).

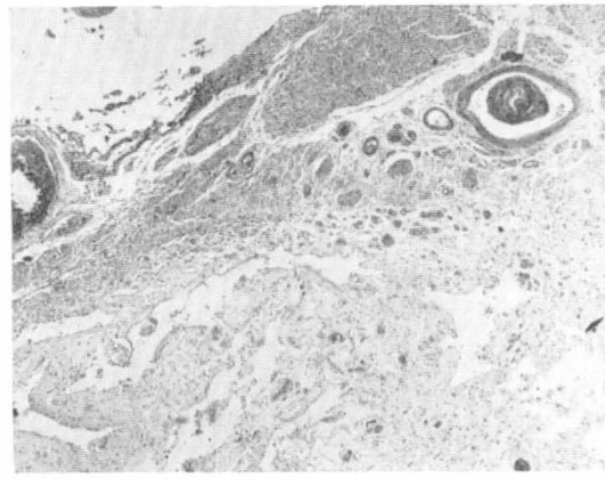

Fig. 6A

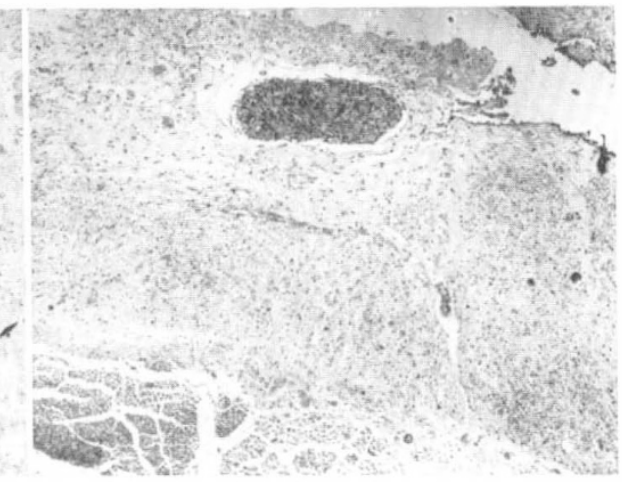

FIG. 6B

Figure $6 \mathrm{~A}-$ Transverse section at $\mathrm{L}_{5}$ showing numerous cavities in the cord with some small bundles of regenerated nerve fibres in the thickened pia arachnoid on the dorsolateral aspect near the dorsal root entry zone, 7 years after fracture dislocation Di2-LI. $($ H. \& E. $\times 2$. $)$ Figure $6 \mathrm{~B}$-Large bundle of regenerated nerve fibres in the region of the anterior horn at $\mathrm{L} 4$ with a large transversely elongated cavity dorsal to it. (H. \& E. $\times 36$.)

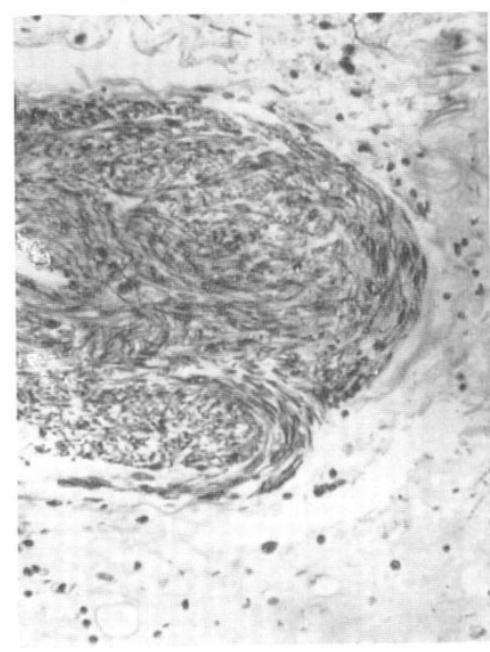

FIG. 6C

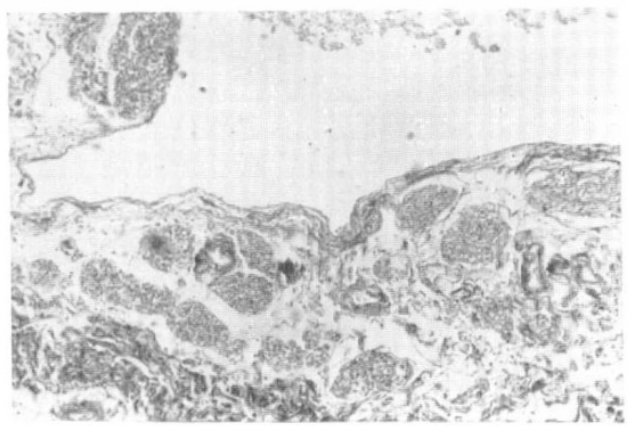

FIG. 7

Figure 6c-Medial part of same bundle showing resemblance to an amputation neuroma. (Silver $\times$ 165.) Figure $7-$ Transverse section at $\mathrm{L}_{5}$ showing bundles of regenerated nerve fibres ventrolateral to cystic cavity. There is dense fibrous
chnoid, $\mathrm{I}_{4}^{3}$ years after fracture dislocation $($ Myelin $\times 60$.
(O) 
(8) F. D. Male, aged 39. Fracture dislocation D4-5. Survived $17 \frac{1}{2}$ years. At the site of maximal damage at $\mathrm{D}_{5}$ there was a transversely elongated cavity with huge bundles of regenerated fibres all round the cyst, especially on its dorsal aspect. They were also present in the thickened pia arachnoid on the dorsolateral surfaces and in the ventromedian fissure (fig. 5). These bundles were less numerous at D6 and 7. The fibres in the ventromedian fissure could be traced up to D2 and down to Di2.

(9) J. H. Male, aged 48. Fracture dislocation DI2 on Li. Survived I year. Below the level of maximal damage $\left(\mathrm{S}_{3}, 4\right)$ the ventral half of the cord and the ventromedian fissure at $\mathrm{S}_{5}$ contained several bundles of regenerated fibres.

(I0) J. D. Male, aged 48. Fracture dislocation DI2 on LI. Survived 7 years. No cord was recognisable at $S_{I}$ at which level there was a mass of bundles of regenerated nerve fibres surrounded by dense fibrous tissue. Many bundles of regenerated fibres were present in the thickened pia arachnoid on the dorsal aspect of the cord (fig. 6A). They also surrounded a cavity in the cord at $\mathrm{L}_{5}$ and $\mathrm{L}_{4}$ and also below the level of maximum damage in the $\mathrm{S}_{2}$ and 3 segments. A particularly large bundle was present at $\mathrm{L}_{4}$ (figs. $6 \mathrm{~B}$ and $\mathrm{C})$.

(II) C. T. Male, aged 52. Fracture dislocation Di2 on LI. Survived IO $\frac{3}{4}$ years. Cord replaced by large cystic cavity at L4. Numerous bundles of regenerated fibres in the ventral and lateral walls of smaller cavity at $\mathrm{L}_{3}$ and at $\mathrm{L}_{5}$ (fig. 7).

(I2) L. S. Male, aged 37. Fracture dislocation Di2 on LI. Survided I8 $\frac{1}{4}$ years. The upper 2 sacral segments were replaced by a few widely separated bundles of regenerated nerve fibres with intervening collagen.

In these 12 cases the bundles of regenerating nerve fibres were seen in four situations. Most commonly they were present in the thickened pia arachnoid on the dorsal or dorsolateral aspect of the cord adjacent to the dorsal root entry zone, or in the ventromedian fissure. In the cord itself they were present in widely separated bundles replacing cord substance with a loosely arranged fibro-glial meshwork intervening or they were more compactly arranged in the wall of the cystic cavities frequently found in the damaged segments. Occasionally they were seen in perivascular spaces or attached to the wall of small arteries. In the three cases where the cervical cord was injured, the regenerated fibres were found above the site of maximal damage in two cases and below in one. In the five cases where the thoracic cord was injured, the fibres were encountered above the site of maximal damage in two and both above and below in three. In the cases of lumbar cord damage, three out of the four showed regeneration above and below the destroyed segments whilst in the remaining case regenerating fibres were found only below the lesion.

\section{DISCUSSION}

The histological study of these 12 cases shows that regenerating nerve fibres grow both in the damaged spinal cord and in its thickened surrounding pia arachnoid. In three of the cases the bundles of intramedullary fibres had become large with whorls of intertwining fibres and fibroblastic cells resembling an amputation neuroma. The relationship of these to the cases of intramedullary neuromata recorded in the literature has been noted (Wolman, I966).

Barnard and Carpenter (I950) considered that growth of nerve fibres across a lesion after partial or complete spinal cord transection was possible, but the frequent failure resulted from the formation of a dense connective tissue scar in the wound and the absence of neurilemma sheaths. The blocking effect of glial 
scarring was shown in the cat by Clemente and Windle (I954). This connectivetissue scar or pial-glial barrier was a most prominent feature of the traumatic cases with long survival in this present series. In an attempt to inhibit this, Windle and Chambers (I950) used pyrogenic drugs and these were found to aid regeneration (Windle, I954; Windle et al., 1956). McMasters (1962) found that ACTH also helped in the return of both motor and sensory function but this occurred in only a few animals out of a large series. A similar small number of animals regaining both sensory and motor function was reported by Freeman et al. (1949) and Freeman (1952). Sensory recovery always preceded the appearance of motor activity and in some animals return was limited to sensory function. In none was there recovery of motor activity alone.

Histologically demonstrable regeneration across the gap in the completely transected spinal cord of the cat protected by a Millipore shield was shown by Campbell et al. (1957) and Bassett et al. (1959). Growth of axons across the junctional zone was shown to commence at about the end of the third week and by 30 days many unmyelinated axons had bridged the gap (Campbell et al., 1958). Using bioelectric criteria, Thulin (I960) considered that the axons entering the gap were outgrowths of propiospinal neurons of the lateral columns mainly and of the ventral columns. A comparison of regeneration of the spinal cord with that of peripheral nerves (Noback et al., I959) showed several similarities such as the presence of a plasma clot in the gap between the stumps followed by an outgrowth of mesenchymal and angioblastic cells from the stumps into the clot and the guiding of regenerating nerve fibres towards the opposite stump by these cells. The main differences (Noback et al., I96I) comprised the many Schwann cells and few macrophages found in peripheral nerve gaps compared with the numerous macrophages in spinal cord gaps. Nerve regeneration occurred from both spinal cord stumps into the gap whilst in the peripheral nerves only axons in the proximal stump regenerated. Although myelinated axons were present in regenerated peripheral nerves by 30 days, none were observed in regenerated spinal cord nerves at this time, due probably to the apparent absence of oligodendroglial cells in the gap at this stage.

Evidence for the way in which cord regeneration is initiated was obtained by Duncan and Bellegie (I948) who implanted fragments of Walker rat sarcoma into spinal cord gaps and found the tumour to be invaded by nerve fibres from both the posterior white columns and the dorsal nerve roots. That fibres from spinal nerve roots will penetrate and grow into the spinal cord was shown by Jakoby et al. (1960). The early stages of regeneration in the rat in the first I6 days after trauma were examined by electron microscopy by Schlote (I964). Axonal regeneration from dorsal roots into the dorsal columns of the transected rat spinal cord together with Schwann cells was studied under the electron microscope by Lampert and Cressman (1964).

It is not known whether all nerve fibres of the spinal cord share equally the potential for regeneration after severance. Regeneration has been described in axons of the lateral and ventral columns and in the dorsal funiculi but the recent studies of Thulin (I960) suggest that in the cat the neurons of the propriospinal system are most active. There is as yet little information on the nature of the terminations of such regenerating fibres and whether they make synapses (Windle, I956, I962). 
In this process of regeneration it is theoretically possible for the fibres to have originated from several sources. Thus the fibres could be either downgrowths from the long or short descending pathways of the spinal cord from above the site of injury or alternatively upgrowths from ascending fibres from below. Regenerating fibres could also have sprouted from residual anterior horn cells in the damaged segments or in those just adjacent. They could have originated also from nerve cells in the posterior root ganglia entering the cord in damaged dorsal nerve roots. Although contributions to the cord from either dorsal or ventral nerve roots are probably more important than central regeneration, they also occur within the pial-glial membrane. The possibility of perivascular nerve fibres, which accompany intramedullary arteries into the cord, contributing to the process of regeneration was also considered.

It is thought that evidence for most of these mechanisms was demonstrated in the twelve examples recorded. A very frequent site for bundles of regenerated nerve fibres was in the pia arachnoid on the dorsolateral aspect of the cord above the level of maximum damage and in the dorsolateral quadrant of the cord near the dorsal root entry zone. The origin of these nerve fibres was clearly in the posterior nerve roots and ganglia. This power of growth of peripheral nerve fibres can persist for a very long time and was demonstrated as long as 3I64 days after nerve injury in a human case reported by Bowden and Guttmann (1944). The cases with regenerating nerve bundles in the posterior columns suggest that the fibres were growing upwards either from dorsal roots or from the lower cord segments as the regenerated fibres were below segments of complete cord destruction with cyst formation, making incomplete transection of the cord with some residual nerve bundles most unlikely. In the two cases with regenerated fibres above the maximal damage the presence of these fibres in the ventromedian fissure suggests an origin from the nearby intact horn cells or from decussational fibres. The two cases which were most difficult to interpret occurred after a thoracic spinal injury and after a lumbar injury which caused a large cystic cavity to form in the damaged segments. In the upper part of this were numerous bundles of regenerated fibres situated all round the cavity in its glial wall. Although some of these may have originated from posterior roots, anterior horn cells, or perivascular nerve fibres the large numbers of bundles evenly distributed round the cavity was suggestive of an origin from inside the cord from more rostral levels, possibly from short propiospinal fibres rather than from the longer tracts in view of the work of Thulin (I960). In none of these cases did serial sectioning help to elucidate whether any of these fibres established synapses, as the majority seemed to taper out in either the fibrous thickening of the pia or in the dense gliosis.

Although anatomical regeneration at the site of complete severance of the spinal cord has been observed in adult rats, cats, dogs, monkeys and man and there is ample evidence that the regenerated nerve fibres are capable of conducting nerve impulses in the cat, there is little evidence as yet that true physiological recovery, either motor or sensory, has been attained in mammals. Until this can be proved, no practical use can be made of these findings, but the therapeutic possibilities and importance of these observations are obvious. In the production of spasticity after spinal cord injury several factors both peripheral, in the muscles, and central, in the lower segments of one cord, play a part. That sprouting of afferent terminals to fill the gaps left by the degeneration of descending tracts may 
be a major cause of the exaggerated reflexes and spasticity of paraplegia is suggested by the physiological and anatomical observations on the transected spinal cords of monkeys and cats made by McCouch and co-workers (I958). The problem of whether the bundles of regenerated nerve fibres seen in human cases of traumatic paraplegia have any functional significance can only be solved by the careful and thorough recording of physical signs on examination at regular intervals from the time of initial injury and correlating alterations, if any, with subsequent histological findings. This sort of study remains for the future but a start has been made on current cases.

\section{SUMMARY}

During the course of investigating a series of 76 patients with traumatic paraplegia at autopsy, a detailed histological examination of the spinal cords was carried out by serial sectioning. Evidence of well-developed axon regeneration in or near the damaged segments was found in 12 cases, and this is presented.

In these cases showing regeneration, the time elapsing after injury ranged from 12 months to 32 years. The regenerating axons occurred in small bundles both above and below the level of maximal cord damage which was situated in cervical (three cases), thoracic (five cases), and lumbar (four cases) segments. The possible sources of origin of these axons as seen in serial section or deduced from their positions are discussed.

A historical review of the pertinent literature on regeneration in the spinal cord after injury both in man and in the experimental animal is included.

\section{ACKNOWLEDGMENT}

My thanks are due to Dr. A. G. Hardy and Dr. N. Watson of the Spinal Injuries Centre at Lodge Moor Hospital, Sheffield, under whose care these cases were admitted for granting me the facilities to obtain the material as well as full access to their clinical records.

\section{REFERENCES}

Barnard, J. W. \& Carpenter, W. (I950). F. Neurophysiol. 13, 223.

Bassett, C. A. L., Campbell, J. B. \& Husby, J. (1959). Exp. Neurol. I, 386.

Bowden, R. E. M. \& GutTMAnN, E. (1944). Brain, 67, 273.

Cajal, S. R. Y. (I928). Degeneration and Regeneration of the Nervous System. Translated by MAY, R. M., Vol. 2, pp. 558-582. London: Oxford Univ. Press.

Campbell, J. B., Bassett, C. A. L., Husby, J. \& Noback, C. R. (I957). Science, 126, 929. Campbell, J. B., Bassett, C. A. L., Husby, J. \& NobaCk, C. R. (I957). Surg. Forum, 8, 528. Clemente, C. D. \& Windle, W. F. (I954). F. Comp. Neurol. roi, 69i.

DENTAN, P. (1873). Quelques recherches sur la regénération fonctionnelle et anatomique de la moëlle épinière. $44 \mathrm{pp}$. Berne: Diss. Inaug. C. J. Wyss.

DruCKMAN, R. \& MAIR, W. G. P. (1953). Brain, 76, 448.

Duncan, D. \& Bellegie, N. J. (1948). Texas Rep. Biol. Med. 5, $46 \mathrm{I}$.

Eichiorst, H. \& Naunyn, B. (I874). Arch. exp. Path. Pharm. 2, 225.

Feigin, I., Geller, E. H. \& Wolf, A. (I95I). F. Neuropath. exp. Neurol. 10, 420.

FREEMAN, L. W. (I952). Ann. Surg. 136, I93.

Freeman, L. W., Finneran, J. C. \& Schlegel, D. M. (1949). Amer. F. Physiol. 159, 568.

Gerard, R. W. \& Grinker, R. R., (I93I). Arch. Neurol. Psychiat. 26, 469.

HENNEBERG, R. (I907). Charite-Ann. 3I, I6I.

Hooker, D. (I9I 5). F. comp. Neurol. 25, 469.

Hooker, D. (I917). F. comp. Neurol. 27, 421. 
HOOKer, D. (1925). F. comp. Neurol. 38, 315.

Hughes, J. T. \& Brownell, B. (1963). F. Neurol. Neurosurg. Psychiat. 26, 528.

Jakoby, R. K., Turbes, C. C. \& Freeman, L. W. (1960). F. Neurosurg. 17, 385.

Klaue, R. (I949). Wien Z. Nervenheilk. 2, 488.

LAmpert, P. \& CRessman, M. (I964). Lab. Invest. I3, 825.

LiU, C.-N. \& Chambers, W. W. (1958). Arch. Neurol. Psychiat. 79, 46.

Lorente De Nó, R. (I92 I). Trab. Lab. Invest. Biol., Univ. Madrid, I9, I47.

McCouch, G. P., Austin, G. M., LiU, C. N. \& LiU, C. Y. (I958). ै. Neurophysiol, $21,205$.

McCreight, J. (1924). Anat. Rec. 27, 38.

McMasters, R. E. (I962). F. Comp. Neurol. II9, II3.

Marinesco, G. \& Minea, J. (I906). Nouv. Iconog. Salpét. 19, 4 I7.

Minor, L. (I904). Handbuch der Pathologischen Anatomie der Nervensystems, by Flateau, Jacobson \& Minor, Vol. 2., p. I029. Berlin: Karger.

Murray, G., Ugray, E. \& Graves, A. (1965). Amer. F. Surg. I09, 406.

Nageotte, M. J. (I899). C.R. Soc. Biol., Paris, 51, 738.

Nicholas, J. S. \& RudNicJ, D. (I933). F. exp. Zool. 66, i93.

Noback, C. R., Bassett, C. A. L., Thulin, C.-A., Husby, J. \& Campbell, J. B. (I959). Anat. Rec. I33, 3 I6.

Noback, C. R., Thulin, C.-A., Bassett, C. A. L. \& Campbell, J. B. (i96i). Acta Anat. 47, I 44 .

Piatt, J. (1955). F. exp. Zool. 129, I77.

RAyMOND (I893). Arch. Neurol. (Paris), 26, 97.

Schlote, W. (I964). Acta Neuropath. 4, I38.

STEPHENS, L. B. (I959). F. exp. Zool. I4I, 353.

Stroebe, H. (1894). Beitr. Path. Anat. I5, 383.

Sugar, O. \& Gerard, R. W. (I940). F. Neurophysiol. 3, I.

Thulin, C.-A. (1960). Exp. Neurol. 2, 533.

Windle, W. F. (1954). Trans. Amer. Neurol. Ass., 79th Ann. Meet., p. 233.

Windle, W. F. (I955). Regeneration in the Central Nervous System. Springfield, Illinois: Charles C. Thomas.

Windle, W. F. (1956). Physiol. Rev. 36, 427.

Windle, W. F. (I962). Basic Research in Paraplegia, p. 5. Edited by J. D. French \& R. W. Porter. Springfield, Illinois: Charles C. Thomas.

Windle, W. F. \& Chambers, W. W. (I950). F. comp. Neurol. 93, 24 I.

Windle, W. F., Littrell, J. L., Smart, J. O. \& Joralemon, J. (I956). Neurology, 6, 420.

Wohlfart, G. (I96I). World Neurol. 2, I87.

Wolman, L. (I966). Paper 54. Presented to Path. Soc., Gt. Britain and Ireland, II3th Meeting, Liverpool, July I966. Synopses p. 20. (To be published.)

\section{Discussion}

Sir Ludwig (England). I was very impressed with the papers of the pathologists, particularly with the findings of neuroma formation within the spinal cord. Although Dr. Wolman showed us that this can occur without alcohol block it is interesting that this was also found after alcohol block. However, it must be remembered that these were all traumatic patients and the neuroma formation might have been present long before the alcohol block. With regard to the relationship of these findings and recovery of function I think we have to be very careful. Recently I saw in my Unit in Cardiff a woman who has survived a paraplegia below $\mathrm{T}_{5}$ for 25 years. During the last three years she complained of pain in her lower back radiating into the left leg. On examination I found that she had definitely some appreciation to deep pressure with correct localisation in that left leg. I had known her symptomatology for many years and it was the first time that I discovered this appreciation to pressure on the left side only. It is very difficult to say what the anatomical basis of this is but, from what we have seen from the pathologists, there might be a possibility that some of the fibres which have not been completely 
severed initially might have regenerated. Of course, this has nothing to do with the phantom sensation which many paraplegics have which they project into the paralysed area as a result of a continuous irritation of the distal part of the proximal stump of the spinal cord.

Walsh, F. (England). I would like to ask Dr. Wolman. In the cases in which he found this neuroma formation, did he notice any particularly large amount of root pain or local pain in the history before he had the specimen $\mathrm{I}$.

Wolman, L. (England). No, I do not think there was any evidence of root pain particularly. There were three cases that had well-developed neuromata. We did not know. we were going to find these neuromata until long after we had done the autopsy when the histology came through. There was no evidence beforehand to make one suspect that there might be some regeneration in any of these cases. I think that the importance from my point of view of these findings is that it does show how worth while it is examining in detail all cords of all paraplegics, even if superficially they look a most unattractive sort of proposition and not likely to yield anything fruitful. One just started doing these cases routinely, and it is amazing how many interesting aspects of pathology one finds which, of course, can lead now to a more accurate assessment. If we come across any of the cases like Dr. Guttmann has just mentioned where there has been some evidence of recovery of function, I think these are terribly important to follow up and eventually if possible to do the autopsy and examining. The only way one can assess whether these fibres are doing anything worth while at all is by a very careful correlation with the clinical findings over the years.

Hardy, $A$. (England). I have had the pleasure of doing part of this work with Dr. Wolman and I would like to put in a special plea. We have now got to the stage when we have got to say how complete is complete, and I would like to put in a plea that these examinations are absolutely vital not only with a pin, wool and pressure but we have to become aware of these perverted sensations to pressure which Professor Guttmann has mentioned and it is terribly important. I know the case very well that Dr. Wolman is talking about and we weren't aware that clinically he had perverted sensations but, looking back on it, I rather think he had, and therefore one wonders how complete he was, and I wonder whether he was complete from the very beginning. Unless we are right in our assessment at the beginning we can have wrong interpretations at the end.

Sir Ludwig. I quite agree with Dr. Hardy. Only very careful neurological examination again and again in these so-called old cases will clarify whether there is real proper regeneration of the spinal cord in man. We know that in the amphibia experimental studies have shown that there is some regeneration but so far all the publications on return of function due to regeneration of the spinal cord in dogs and other mammals are absolutely unreliable. All the publications which show that the cat or the dog can stand after cord transection do not mean anything. The spinal man can stand too. They stand due to static reflexes of the isolated cord and action of the normal back muscles above the transection, which is an old story which was published for the first time in 1905 by Phillipson, a physiologist in Belgium.

Kerr, $W$. (Scotland). Two points I would like to say about this pathology. One patient whom I know who is not under my direct care but visited the Edinburgh Unit was, as far as she was aware, complete but she did say that she had some deep sensation on percussion of the pelvis and she developed pain in her pubic area. She is a very active sportswoman and I thought that possibly she had pulled her adductor muscle because I then found there was localised tenderness in the pubis. I took a syringe of local ahaesthetic, I put it into the adductor insertions, she felt the needle going into her big toe on the same side.

On regeneration, I was most impressed with an experiment carried out in Canada about two years ago and the research worker gave an address at the Royal College of Surgeons, Edinburgh. The experiment was in rats, he showed a film after cord 
transection, how the rat could stand but with the feet strongly plantar flexed so that the feet were dragging on the ground as the rat attempted to walk along. Then he showed us another film of rats in which the cord had been completely transected so that a thread passed from behind and brought forward through the cord completely passed through sutured, and then intraperitoneal injections of embryonic nerve tissue were given. Histological examinations showed regeneration which occurred but was stopped by gliosis. The gliosis is quicker and the axons cannot get through, but in this case the regeneration was speeded up and did get through, and these rats actually did walk to a certain extent and they were no longer dragging their feet with a reflex movement and the dorsum of the foot dragging on the ground. I am not suggesting that this is of any practical value in traumatic paraplegia, because a large section of the cord will be damaged and there will be associated bruising above and below the transection. To resect such a large area and try to bring it together, suture it and fill the patient with embryonic nerve tissue may be out of this world at present.

Grogono, B. F. S. (Canada). I think Mr. Kerr may have been referring to Dr. O'Callahan, who did this work for a thesis while working in Edmonton, he is now in Toronto. I spoke to him at length about his project and read his thesis, and his evidence was that 5 out of 35 rats who had this injection were able to walk and behaved differently from a controlled series who only showed reflex action. There was histological evidence of regeneration and there was evidence of conduction if one stimulated the cord above the level of the transection.

Walsh, F. (England). Dr. Hardy stressed the importance of examining very carefully neurologically all cases, and I would like to add to that our plea that when we admit patients for a check-up we do not start our examination at the known lesion and work down but work up as well, and I think we will find rather more cases of ascending degeneration.

$M c$ Sweeney, $T$. (England). I think Dr. Hardy raised a very fundamental point when he said how complete is complete, and I would like to raise the same plea in connection with spasticity, how spastic is spastic. As Dr. Frankel has mentioned, we all recognise the beneficial type of spasticity. Dr. Weiss showed us a graphic method of recording spasticity and since we know that sepsis, urinary infections, drugs, etc., can affect spasticity we really have got to the stage now where we must have a fundamental base-line, particularly in connection with the paper on the muscle transferences. You will remember I asked you how do you decide which muscle to transpose or tenotomise. I can see from orthopaedic principles, in particular in dealing with cerebral palsy, that in fact transferences or tenotomies may make the patient even worse.

Sutcliffe Kerr, $A$. I was very struck with Dr. Hughes' material showing what I have always suspected that one cannot control where a substance, lethal to nerve roots, alcohol or phenol, will go once it has been introduced into the spinal theca. We have always adopted the technique of careful positioning of the patient immediately after the introduction either of alcohol or phenol; where phenol has been used radiological control with myodil as the opaque medium has told us that the phenol has predominantly gone on to the anterior nerve roots. But Dr. Hughes' material clearly shows that the alcohol has affected very largely the posterior nerve roots, probably the anterior nerve roots as well and they have regenerated, but nevertheless I think it undesirable that the posterior nerve roots should be damaged. And if the posterior nerve roots are damaged by the alcohol what is happening to those nerve roots which are subserving the bladder function. In our patients who have had unsatisfactory bladder function and who also have had spasticity we have regarded the alcohol block as a very useful procedure because then we could knock out the undesirable effects on the bladder simultaneously with abolishing the spasticity of the skeletal muscles.

Meinecke, F. W. (Germany). I was very interested in Dr. Hughes' findings on the difference in degree of destruction between the posterior and anterior roots. I would 
like to ask whether the patients, after the alcohol block, were immediately turned over or not, as this may perhaps explain the damage to the posterior roots.

Sir Ludwig. As far as our own patients are concerned, the intrathecal injection of alcohol is done in the left lateral, tail-up position, and the patient is placed immediately afterwards slowly on to his back and then on to the other side to ensure that the alcohol involves all the posterior and anterior roots of the spinal cord itself.

Wolman, L. (England). I feel that some comments should be made about Dr. Hughes' paper because I think it is an extremely valuable contribution.

First of all, I would like to point out that the effects he showed as due to alcohol are non-specific effects. Most of the effects that he described do occur with other intrathecal drugs which are recognised to damage the nerve fibres and nerve cells. I think the same sort of effects are seen with phenol and alcohol, and they have also been described in the few cases of damage to the spinal cord after spinal anaesthetic. Another point I would like to make is that in our material we have also seen this thickening of the arachnoid around the spinal cord after alcohol. It is usually diffuse, but we have got examples where it is a patchy sort of thickening resulting in the classical appearance of cystic arachnoiditis with loculated cysts of fluid in the thickened arachnoid around the spinal cord. Another point worth mentioning is that the alcohol injected into the spinal theca can track into the cul-desac of the subarachnoid space which extends around the posterior root ganglia. Dr. Hughes did not mention whether he had looked at the posterior root ganglia, but we have seen damage to the nerve cells in the posterior root ganglia in those cases that have had intrathecal injections. If one knocks out the cells in the posterior root ganglia one would not expect regeneration in the posterior nerve roots anyway. I think another effect of the chemical agent on the nerve fibre can result from the extradural escape of the injecting agent through the lumbar puncture wound. I think all these effects of chemical agents have to be taken into account in interpreting the pathology.

Sir Ludwig. I think we have had a really good discussion on this most important problem of treating spasticity in paraplegia and tetraplegia, and it is now my duty to summarise some of the points made with a few personal comments.

I would like to start with the remarks of the last speaker, Dr. Wolman. When I published my first reports on intrathecal alcohol block exactly 20 years ago in the Royal Society of Medicine, I reported the first two patients in whom I transformed intractable spasticity in a complete cord lesion into a flaccid one by an intrathecal alcohol block. This was the first time that it was attempted to treat intractable spasticity by a chemical procedure. Dr. Hughes mentioned Dogliotti who introduced intrathecal alcohol injection in 1930. However, this was done from completely different indication, namely for the treatment of intractable pain in patients suffering from carcinomatosis. He injected small doses to knock out the radicular pain. But, this method was soon abandoned because he produced paraplegia. This observation induced me to use the alcohol block to transform the spastic paralysis into a flaccid one chemically instead of by major surgical procedures such as anterior rhizotomy. The 6th case shown in the table of Dr. Hughes had survived over 20 years. He was one of the first two patients where I injected only 0.4 or up to $2 \mathrm{cc}$. alcohol into the thoraco-lumbar junction of the cord direct. Dr. Hughes will continue to examine the case in more detail, because it would be interesting to find out now after 20 years what effects the alcohol has had on the spinal cord itself. I would assume that in these two cases the alcohol must have damaged not only the posterior part but the whole conus and epiconus.

It was two years later that Bors and Sheldon published the paper on intrathecal alcohol block using large doses, 15 cc., just to knock out the spinal roots. I have adopted this method, because it is technically much easier, but I found that as a rule 5-8 cc. are quite sufficient to produce a lasting beneficial effect. It is known that if, during rhizotomy, one or two roots of the flexor muscles are left intact, the spasticity might return. The same may happen after both intrathecal alcohol or phenol injections. Obviously, in 
such a case, it is very easy to repeat either the alcohol or phenol injection but to do another laminectomy is, of course, much more difficult, especially if one has to operate in a scarred area of the cord resulting from the previous operation or in traumatic lesions as a result of the initial injury. I agree with Mr. Sutcliffe Kerr that it is very difficult to control the extent of the effects of alcohol or phenol following intrathecal injection. That is the reason why I have always warned not to use the intrathecal alcohol block in incomplete lesions with good voluntary or reflex functions of the bladder and sexual function. This applies, of course, also to phenol. I have always been very sceptical to the claims-and Dr. Nathan knows my views-that with intrathecal phenol injections one can single out special spinal roots for blocking without affecting the bladder function in incomplete lesions. In fact, we have admitted patients after this procedure and found the bladder permanently paralysed.

With regard to surgical procedures on tendons and muscles, I was very impressed by the scepticism and disappointment as expressed by a very experienced orthopaedic surgeon like Mr. McSweeney with regard to transplantation of tendons in spasticity, in particular in the upper limbs. I can only amplify what Mr. McSweeney has said from our experience. Some patients have been admitted after these transplantations. In theory these are very beautiful, but in the end the disability in the upper limbs was much worse than before the operation, especially after transplantation of flexors of the wrist on to the extensor digitorum. One should take notice of what $\mathrm{Mr}$. McSweeney has said.

I come to the last point-the local injection of phenol into the peripheral or motor points. This seems to me a practical way in the treatment of spasticity especially in incomplete lesions. I think proper examinations before and afterwards and follow-up are absolutely necessary to give us in the future a clear picture about the value of this procedure. Here I have a little criticism of the film Dr. Glass has shown us. Unfortunately, the degree of contracture of the long flexors and flexor pollicis longus before the injection was not shown in the film, and this would have been important for comparison. I am delighted that these two procedures have been taken up because it will improve greatly the clinician's knowledge of the anatomy of the entry of the branches of peripheral nerves into individual muscles as well as their functions. In this connection, clinicians should become familiar with the classical work of Duchenne de Boulogne and Otfrid Foerster.

Finally, it is essential to ascertain if possible electromyographically, before injecting peripheral nerves or motor points for the treatment of spasticity which muscle or muscle group is preponderent and after blocking this muscle examine the effect on the whole flexion or extension synergy.

\title{
(B) ANKYLOSING SPONDYLITIS
}

\section{TRAUMATIC PARAPLEGIA AND TETRAPLEGIA IN ANKYLOSING SPONDYLITIS}

\author{
By Sir Ludwig Guttmann, C.B.E., M.D., F.R.C.P., F.R.C.S. \\ National Spinal Injuries Centre, Stoke Mandeville Hospital, Aylesbury
}

Since Bechterew (1894, I897), Strümpell (I897) and Pierre Marie (I898) recognised ankylosing spondylitis as a systematic inflammatory disease of the spinal column resulting in progressive rigidity of the spine and the thorax, a considerable literature on aetiology, incidence, sex, symptomatology, pathology and therapy, 